\title{
TREM DA SERRA: A(S) SAGA(S) POÉTICA(S) DO(S) IMIGRANTE(S) ITALIANO(S) NA SERRA GAÚCHA
}

\author{
Ana Boff De Godoy
}

RESUMO: This paper is an analysis of the prosaic poem Trem da serra: poema da região colonial italiana, written by the South-Brazilian writer Ernani Fornari, under the light of travel literature. The travel, here, is seen not only as the spatial physical displacement of the narrator poet but also as a displacement throughout time both of the period of the travel itself, and of the time of memory, which is revisited while the train rolls through the beautiful landscape of Brazilian southern mountains. Moreover, following the situation presented by the author himself, the travel is also analyzed in terms of the identity quest lived by the son of Italian immigrants, who wavers between two cultures.

PALAVRAS-CHAVE: literatura de viagem, imigração italiana, poesia serrana, Ernani Fornari.

\footnotetext{
Ana Boff De Godoy é licenciada em Letras (português / Italiano) pela UFRGS; Mestre em Literatura Brasileira (PPG - Letras / UFRGS), bolsista CAPES.

O presente trabalho foi desenvolvido como monografia para a disciplina "Trajetórias da narrativa brasileira" do PPG em Letras da UFRGS, ministrada pela Prof. Dra. Gínia Maria de Oliveira Gomes, e foi apresentado no evento comemorativo dos 125 da Imigração Italiana no RS intitulado "O ensino do italiano das universidades do Rio Grande do Sul", promovido pelo Departamento de Línguas Modernas do Instituto de Letras da UFRGS, Setor de italiano, realizado dia 14 de setembro de 2000 .
} 
Trem da serra: poema da região colonial italiana, obra do filho de imigrantes italianos Ernani Fornari ${ }^{1}$, é a reunião de poemas prosaicos que se constituem, na totalidade, em um livro de viagens. Utilizar-se-á a palavra no plural (viagens) - assim como o título desse trabalho também aponta a pluralidade -, porque se acredita que não existe uma só forma de viagem e que o trajeto físico percorrido é somente um primeiro passo (ou a aparência da viagem) em direção a um movimento muito mais profundo, muito mais intenso e complexo do que um deslocamento espacial.

Ernani Fornari, ao lado de Olmiro de Azevedo, é considerado o introdutor da assim chamada Poesia Serrana. Esse dado permite que se faça uma aproximação da obra em questão, no âmbito da formação da literatura, com o Romance de Formação (Bildunsroman):

No Bildungsroman é o próprio sujeito que emerge no seu percurso, o sentimento do mundo sintoniza-se ao autoconhecimento, o aprendizado é sempre também de si mesmo. Assim como os deslocamentos no espaço, as paisagens por que passa estão impregnadas de tempo, história. E o itinerário geográfico desses sujeitos-em-formação converte-se em geral numa espécie de inventário do tempo também (SÜSSEKIND, 1990, p.110).

O eu-lírico / narrador que emerge de Trem da serra é um desses "sujeitos-em-formação" por excelência, não só porque a obra se insere em um contexto significativo de transformação da Literatura Brasileira (foi escrita em 1928), mas também devido à origem do autor. Darcy Ribeiro (1995, p. 438) lembra que as primeiras gerações descendentes de imigrantes ainda se formavam e se mantinham "no espírito e segundo as tradições dos pais e avós imigrados". Assim, não é à toa que Fornari elege como lugar a ser (re)visitado a serra gaúcha (quase totalmente dominada pela imigração italiana, secundada pela germânica), da mesma forma que não pode ser deixada para segundo plano a discussão identitária que tal deslocamento geográfico propicia.

A viagem que o eu-lírico / narrador de Trem da serra faz é, então, múltipla. Sua base é o deslocamento geográfico pelas cidades de colonização italiana através de um trem, mas essa viagem física se transforma em

${ }^{1}$ ERNANI GUARAGNA FORNARI (1899 / RS - 1964 / RJ), nasceu na cidade de Rio Grande (RS), filho do casal de imigrantes italianos (provavelmente toscanos, devido às referências freqüentes ao poeta como "herói fiorentino") Aristides Fornari e Maria do Carmo Guaragna. Foi jornalista, trabalhando em diversos jornais e revistas no RS, entre eles "Diário", "Diário de notícias", "Jornal da manhã" e "Revista do Globo". Já no RJ, foi Secretário Geral da Agência Nacional. Indo morar no exterior, foi $2^{\circ}$ Secretário da Comissão Nacional da UNESCO e Secretário Cultural na embaixada brasileira em Lisboa. Como literato, teve repercussão internacional com suas peças para teatro: Iaiá boneca; Nada; Quando se vive outra vez; Sem rumo; Sinhá moça chorou. Outras obras importantes: Praia dos milagres (poesia); O homem que era dois (romance); A guerra das fechaduras (contos); Enquanto ela dorme (novela). 
viagem pelo tempo ou, melhor dizendo, pelos tempos, isso porque existe um tempo real (tempo de duração da viagem), mas também um tempo da memória individual (em que a infância do eu-lírico / narrador é revelada) e um tempo da memória coletiva (que recupera a história de um grupo específico: dos imigrantes italianos que vieram para a serra gaúcha em busca de esperanças suplantadas pelo seu país de origem).

Mas e qual é o sentido de uma viagem assim aberta, sem objetivos catalográficos e sem retorno? Para Maria Alzira Seixo (1998, p. 23-24) “A questão do sentido só se coloca quando o sujeito entra em relação com um outro, o que sabemos acontecer no plano lingüístico, mas igualmente verificar em termos antropológicos e literários". Logo, assim como a viagem, o seu sentido também é múltiplo, e se manifesta através da linguagem interrelacionada a todos os outros planos por onde ela transita e onde ela é capaz de se concretizar. Ou seja, sempre que a linguagem conseguir transformar um determinado conhecimento ou uma determinada emoção em discurso, e operar esse discurso de forma a descrever esteticamente um percurso significativo que faça representar esse determinado saber ou essa determinada emoção (note-se que os termos aqui estão sendo utilizados de forma genérica) de maneira a provocar alguma mudança no sujeito que o descreve ou que dele participe, está-se diante de uma literatura de viagem $^{2}$.

Partindo da idéia de que o suposto seja verdadeiro, o presente trabalho visa à análise de dois tipos de viagens: i. a viagem geográfica, através de um meio físico (o trem); ii. a viagem pelo tempo em seus desdobramentos, através da memória.

Cabe ainda ressaltar que a dificuldade de enquadramento de Trem da serra nas categorias de literatura de viagem conhecidas corroborou para a presente abordagem, já que veio confirmar o caráter híbrido da obra, inserindo-a na já mencionada literatura moderna de viagem.

Procurando, então, da mesma forma que o autor de Trem da ser$r a$, posicionar-se fora de qualquer categoria preestabelecida e num lugar de permanente movimento e diálogo, partir-se-á imediatamente à análise proposta.

\section{A VIAGEM GEOGRAFICA}

A viagem geográfica descrita em Trem da serra pode ser dividida em 7 (sete) blocos independentes mas ligados entre si, já que o trem (fio

\footnotetext{
${ }^{2}$ Utilizar-se-á o termo "literatura de viagem" preterindo o termo "narrativa de viagem" por se estar tratando de uma obra poética, a qual, via de regra, não é classificada como "narrativa".
} 
condutor dessa narrativa poética), apesar de estar em constante movimento, passa por seis pontos importantes, cidades nomeadas pelo poeta.

O primeiro poema de Trem da serra, "Em viagem" (FORNARI, 1975$, p. 5) $)^{3}$, que constitui, sozinho, o primeiro bloco, funciona como uma introdução, um prólogo à viagem propriamente dita. O interessante é que é um preâmbulo em movimento, já que o trem já está andando quando o livro se inicia sem deixar claro ao leitor qual é o seu ponto de origem. O início da viagem não é, portanto, um ponto fixo, mas um ponto, se assim se pode chamar, fluido. Essa observação se torna importante na medida em que: i. insere todo o movimento poético em uma forma em nada estática, mas de muita fluidez, expressa tanto pelo andamento do trem quanto pelo andamento poético; ii. não aponta para formas fixas, tanto de estrutura quanto de pensamento, optando por deixar o leitor na dúvida, na suspeita, no suspense; e iii. revela uma característica relevante da ambientação criada pelo poeta.

Primeiramente, faz-se importante a distinção entre espaço e ambientação. Segundo Antonio Dimas (em referência a Osman Lins), "o espaço é denotado; a ambientação é conotada. O primeiro é patente e explícito; o segundo é subjacente e implícito. O primeiro contém dados de realidade que, numa instância posterior, podem alcançar uma dimensão

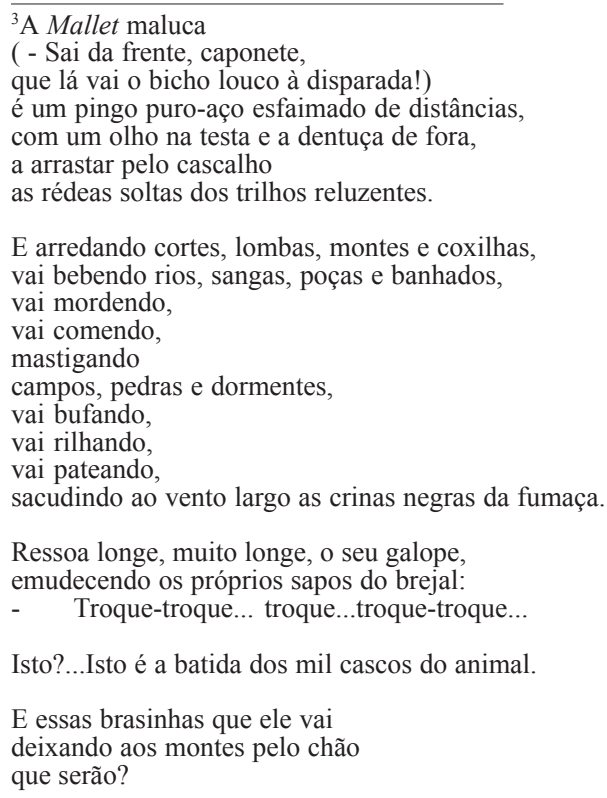


simbólica" (DIMAS, 1994, p. 20). Assim, na presente análise, toma-se o espaço como a referência espacial direta, ou seja, as seis paradas, as seis cidades da serra gaúcha nomeadas pelo poeta; e ambiente ou ambientação como o conjunto narrativo que permeia essa espacialização.

Apesar de não ser objetivo desse estudo a teorização do espaço da narrativa, tomar-se-á, ainda, mais uma categorização estabelecida por Osman Lins e assimilada por Antonio Dimas com o objetivo único de mostrar a riqueza e a maleabilidade da obra em questão. Para tais estudiosos, a ambientação assim se divide em: 1. ambientação franca, "composta por um narrador independente, que não participa da ação e que se pauta pelo descritivismo" (DIMAS, 1994, p.20); 2. ambientação reflexa, "aquela em que 'as coisas, sem engano possível, são percebidas através da personagem', sem a colaboração intrusa e sistemática do narrador que, quase sempre, acompanha a perspectiva do personagem, numa espécie de visão com-partilhada" (DIMAS, 1994, p.22); e 3. ambientação dissimulada ou oblíqua, "na qual os 'atos da personagem [...] vão fazendo surgir o que cerca, como se o espaço nascesse dos próprios gestos' [...] o que faz com que se crie uma harmonização altamente satisfatória 'entre o espaço e a ação"” (DIMAS, 1994, p. 26).

Para que se tente enquadrar a poesia prosaica de Fornari em uma dessas categorias de ambientação é preciso, antes de mais nada, perceber quem é o personagem, ou quem são os personagens, e quem é o narrador. Com certeza, deve-se considerar que o movimento de criação literária se faz distintamente em prosa e em poesia, mas também deve-se ter em mente que se o autor autorizou essa mescla de gêneros, ele autorizou, em conseqüência, a mescla entre narrador e personagem ou ainda entre narrador e personagens. $\mathrm{O}$ eu-lírico não está distanciado nem daquele que narra ou descreve poeticamente assim como não está distanciado daquele que é narrado ou descrito poeticamente. Assim, apenas com esse primeiro poema já é possível colocar-se frente a um impasse: o personagem dessa obra é um eu-lírico de Ernani Fornari, é um outro por ele observado, é a fusão dos dois ou, ainda, é o próprio trem?!

Se se pensa em personagem como persona, tal suposição parece impossível. Mas o poeta se vale da prosopopéia, figura de pensamento ou de retórica que consiste em "emprestar às coisas inanimadas poder de ação peculiar aos seres vivos" (MOISÉS, 1995, p. 422-23). A Mallet (marca da locomotiva do trem) é "maluca", é "bicho louco", "esfaimado", tem "um olho na testa e a dentuça de fora" e arrasta suas "rédeas" pelo cascalho.

Outras aproximações entre o trem e um cavalo podem facilmente ser percebidas em: "seu galope", "a batida dos mil cascos do animal", e em toda a segunda estrofe, que se confirma em movimento riquíssimo de 
anáforas (repetição da mesma palavra na mesma posição), aliterações (repetição da mesma consoante), assonâncias (repetição da mesma vogal) e onomatopéias (figura de efeito sonoro em que o som produzido lembra o som do objeto nomeado): "E arredando cortes, lombas, montes e coxilhas, / vai bebendo rios, sangas, poças e banhados, / vai mordendo, / vai comendo, / mastigando / campos, pedras e dormentes, / vai bufando, / vai rilhando, / vai pateando, / sacudindo ao vento largo as crinas negras da fumaça." (p.5). Essa última figura, aliás, foi bem representativa da fase em que foi escrito Trem da serra. Um poema de Manuel Bandeira, seu contemporâneo, intitulado "Trem de ferro" [coincidência?!] tem movimento muito similar: "Foge, bicho / Foge, povo / Passa ponte / Passa poste / Passa pasto / Passa boi".

Esse movimento fônico aliado à perfeição no uso das figuras faz crescer de tal forma o objeto apresentado - o trem - que ele passa de simples componente inanimado do cenário da serra gaúcha a personagem de suma importância em todo o livro, já que é ele quem garantirá a unidade da obra. A importância do trem como personagem é tanta que chega a apagar completamente (ao menos no poema em questão) qualquer outro personagem ou mesmo o narrador, que ainda não está inserido enquanto tal, isso é, ainda não assumiu uma função característica mantendo-se, até certo ponto e se isso é possível, distante do narrado.

Em relação ao tipo de ambientação escolhido pelo autor, o que se nota é que há um distanciamento do narrador que o permite narrar e descrever, o que poderia consistir em ambientação franca. Mas também se visualiza um comprometimento tal com esse narrar e descrever que o seu resultado é muito mais do que uma simples narração ou descrição, o que poderia levar à ambientação dissimulada ou oblíqua. Não suficiente, percebe-se ainda uma apropriação da visão do personagem (tanto sendo ele o trem ou o alter-ego de Fornari) que faz com que o tal e sua paisagem criada se independizem do narrador, o que cai em ambientação reflexa.

A importância da ambientação, então, aparece desde o início da obra como um "claro enigma": ela é o personagem principal, cenário, motivo lírico, instrumento fônico, sintático, semântico, é o mote e a glosa, é o espaço onde narrador, personagens, sensações e técnicas se misturam. E, mais do que isso, esse lugar não é um ponto fixo, mas em constante movimento, já que essa viagem não tem origem definida, objetivo estabelecido, e o seu ponto de chegada é apenas mais uma parada, momento de fôlego para que a viagem continue.

Antes de se prosseguir na análise da trajetória física que indica Trem da serra, faz-se necessária ainda alguma consideração a respeito da fusão de elementos que constituem a obra. Como já foi referido, o eu-lírico de Trem da serra é também narrador, ele é um personagem (o que sobe no 
trem e faz seu percurso até a última cidade) mas é também vários (porque representante de uma coletividade: a comunidade italiana na serra gaúcha). E esse eu ou esses eus ora se apresentam sob a forma humana, ora sob forma natural (paisagem / espaço) e, ainda, sob a forma específica do trem (ambientação). Assim, tem-se todos esses elementos constituintes de uma narrativa de viagem (personagem / narrador / paisagem / espaço / ambientação / meio de locomoção) sob a tutela de um eu-lírico. A hibridez que se afigura no gênero literário (narrativa de viagem / poema) aparece também na intersecção dos seus vários elementos constituintes.

Sobre o resultado produzido por essa fusão, manifesta-se Flora Süssekind: Epifanias e sensações de passagem rápida e irreversível do
tempo parecem andar juntas. Se, por um instante, sujeito e
paisagem se redimensionam, alterada a luz, fica a impressão
do instante, do tempo que não pára de passar e modificar tona-
lidade e sombras. E, assim, não é só o observador que parece
sujeito à movimentação, também a paisagem adquire repenti-
na mobilidade, imersa não no moto-contínuo das expedições,
mas, junto às demais 'coisas do mundo', no fluxo temporal.
Capaz igualmente de, por instantes, invadir o vaivém espacial
de um viajante (SÜSSEKIND, 1990, p. 122).
égide aparece "Pareci" (FORNARI, 1975, p. 6), primeiSob essa égide aparece "Pareci" (FORNARI, 1975, p. 6), primeira cidade denominada pelo poeta e que inaugura o segundo bloco (em
relação à divisão espacial a que se está dedicando no momento) constituído por 8 (oito) poemas em movimento. O subtítulo de tal poema é "complemento natural", o que parece corroborar com o dito, uma vez que a cidade (ou a sua paisagem) é que funciona como complemento da viagem, e não o trem com seus viajantes os complementos da cidade.

Nesse bloco, o poeta observa a paisagem correndo à sua frente $\mathrm{e}$ a descreve, mesclando essas descrições às questões identitárias, que serão discutidas no próximo capítulo. Os "complementos naturais" predominantes aqui são as vinhas e o contraste paisagístico entre montes e planícies, entre o verde da vegetação e o marrom da terra seca, entre a luminosidade e o opaco. Todos esses elementos descritos tomam vida e são, muitas vezes, relacionados àquele movimento inicial de personificação, de fusão entre os elementos da narrativa poética. Os plátanos, por exemplo, andam em "bando" e são "atropelados" pelo trem, o que rende a esse último umas "taponas frescas de sereno". As montanhas são "pautadas / de vides entrelaçadas em aramados de cinco fios./ [ . . . / E os cachos negros, e os cachos brancos dessas uvas, / que a clave do Sol amadurece, / são as notas musicais, / são as notas das canções / de que seu vinho generoso irá encher / a boca aflita dos que bebem para não sofrer, / e o coração contente dos que bebem por prazer" (FORNARI, 1975, p. 8). 
É sabido que "no Rio Grande do Sul deve-se ao italiano a vinicultura. É de origem italiana o desenvolvimento da indústria do vinho naquele Estado, sendo hoje Caxias [última cidade na rota do poeta], núcleo fundado por milaneses, um dos maiores centros de produção vinícola" (DIÉGUES JÚNIOR, 1977, p.134). Assim, o viajante, ao mesmo tempo em que descreve as belezas que vê, relaciona-as com o que é peculiar da cultura que representa: o vinho e a música.

Essas maravilhas, essas curiosidades reveladas pelo poeta, relacionam-se ao que François Hartog chama de thôma.

...o thôma deve figurar no elenco dos procedimentos da retórica da alteridade. De uma maneira geral, produz um efeito de credibilidade, até porque o narrador não pode deixar de usar essa rubrica que o público espera: se a omitir, arruinará de uma vez seu crédito. Tudo se passa como se estivesse em ação o seguinte postulado: nesses países distantes (ou nesses países outros), não pode deixar de haver maravilhas - curiosidades. [. . .] Enorme beleza, excessiva raridade - esses são os constituintes do thôma. Dito de outro modo, o thôma apresenta-se como uma tradução da diferença: ele é uma das transcrições possíveis da diferença entre aqui e além.

Por outro lado [... . o thôma está ligado ao olho do viajante [. . .]. Com a narrativa etnográfica, é o viajante que se torna a medida do thôma: é com relação a mim [. . . ] que algo se entende como thôma; sou eu que estimo tal paisagem ou tal construção é 'admirável' ou 'extraordinária' (HARTOG, 1999, p. 246-250).

Por esse princípio, percebe-se facilmente que o exaltado pelo poeta não é gratuito. Talvez outro viajante não descendente de italianos não percebesse de modo tão efusivo a beleza das vinhas, talvez outro achasse mesmo interessante os postes e as edificações modernas que contrastam com a paisagem agropastoril. A medida do thôma está, então, ligada diretamente ao seu observador, é ele quem imprime a tonalidade da cor, é ele quem define o grau da beleza do objeto. Assim, a seleção do observado e a forma do mesmo são proporcionais ao desejo de significação do observador. Não se decide o trajeto de viagem sem antes se estabelecer (ainda que inconscientemente) quais os objetivos a serem atingidos, por mais subjetivos que eles sejam.

Da mesma maneira, não se denomina, não se identifica, aquilo que não se pretende deixar explícito. E em Trem da serra, todos os pontos de parada e de observação são denominados, mais do que isso, são reais e explícitos. Conforme Hartog, "o nome próprio, como um lugar que se nomeia, é um ponto de balizamento no seio do grupo social [. . .]. Ele identifica o lugar e confirma o pertencimento do indivíduo que se nomeia a uma classe antecipadamente ordenada" (HARTOG, 1999, p. 257). Portanto, ao selecionar cidades colonizadas por italianos e exaltar a beleza provocada por esse grupo (como já foi dito, foram os italianos que inauguraram o 
plantio da uva no estado), Fornari se coloca, enquanto eu-lírico / narrador, como pertencente, de alguma maneira, a esse grupo (ou, ao menos, como alguém que compartilha de traços desse grupo, ou, no mínimo, simpatiza com eles).

"Seqüências banais" (FORNARI, 1975, p. 16) é o poema que abre o terceiro bloco, constituído por seis poemas, balizado pela parada na cidade de Montenegro. Talvez o fato de ser um bloco de parada, que permite um olhar mais atento aos detalhes e as coisas pequenas (não por sua importância, mas por sua dimensão), justifique a superposição quase total de personagens / paisagem. As pessoas que passeiam pela estação ou mesmo as que estão no trem são observadas nas suas particularidades ("e toda uma turba de louros, morenos e ruivos bulhentos / fundindo ao cadinho do Sol"). O "soldado alourado", "o crioulo fardado", "a rapariga de lábios grossos", "o casal de colonos enlaçados", "o robusto italiano", "os bimbos de maçãs do rosto tão carnudas que não tardarão a estourar de tão maduras", "o beneditino que dorme beneditinamente", "os caixeiros-viajantes", "o menino ruivo"... todos são mais do que "complemento natural" da paisagem, são a própria paisagem, o que não é de se estranhar nessa narrativa poética. Se a "locomotiva foi mamar num reservatório lá distante" o poeta também pode brotar em planta e fazer florir seus personagens: “...se meu sangue / se transformasse, de repente, em seiva, / talvez brotassem novas esperanças em meu peito, / e novas alegrias, como flores, / talvez desabrochassem nos meus lábios" (FORNARI, 1975, p. 18).

A terceira cidade pela qual passa o trem e o poeta é Carlos Barbosa, e é o poema "Ópera da Vila Carlos Barbosa - complemento musical" (FORNARI, 1975, p. 27) que abre o quarto bloco, formado por 4 (quatro) longos poemas nos quais aparece com força total a discussão sobre o clássico e o moderno, o nacional e o multinacional (que será abordada oportunamente). Nesse bloco, a descrição da viagem ainda está focando o homem na sua multiplicidade, sendo acrescido a isso a observação também de seus feitos. O viajante compara constantemente as casas construídas pelos colonos italianos e aquelas construídas pelos caboclos ${ }^{4}$, assim como

${ }^{4}$ De acordo com Darcy Ribeiro (1995, p. 441-442), os caboclos eram, no âmbito da imigração sulina, uma população marginal surgida a partir do entrave latifundiário ocorrido logo nos primeiros tempos da imigração. Diz o estudioso a esse respeito: "Gringos acaboclados que, não possuindo terras, regridem também a uma cultura da pobreza, confundindo-se com os matutos de origem açoriana e com os gaúchos das rancharias, na disputa da terra para trabalhar em parceria. Seus hábitos de trabalho e de lazer, sua dieta, as palhoças que lhe servem de moradia, a penúria em que vivem confundidos, os tornam uma camada só: os marginais da região sulina. A distinção se faz, hoje, tão evidente, que colono, na região gringa, é pequeno proprietário e caboclo é o sem-terra. Em cada categoria confundem-se brasileiros de extração gaúcha ou açoriana e brasileiros de extração gringa, distinguíveis essencialmente por sua posição com respeito à propriedade das terras que cultiva". 
a beleza e viço das plantações dos primeiros e pouco cuidado das plantações dos segundos.

O quarto bloco é composto por 6 (seis) poemas com predominância total das lembranças passadas, já prenunciadas no último poema do bloco anterior. "Visita da saudade" (FORNARI, 1975, p. 35) dá o tom do conjunto de poemas que se passam na cidade de Garibaldi. Muito possivelmente esse retorno ao caráter auto-reflexivo e mesmo autobiográfico se deva ao fato do poeta ter estudado nessa cidade quando da sua juventude, o que, devido a seus bons momentos, tornou Garibaldi uma cidade cara à sua lembrança.

Esse conjunto de poemas sustenta toda uma segunda parada física da viagem. Nessa cidade o trem pára e o poeta desce para rever suas lembranças; pernoita no Hotel Faraon e, no dia seguinte, faz um passeio externo (pela cidade) e interno (pela memória). Apesar de todos os poemas revelarem o passeio concreto por entre ruas e lugares da infância do viajante (o "convento dos capuchinhos", o "Colégio Santo Antônio", a "Coletoria", a "Farmácia do D'Arrigo", o "bilhar do 'seu' Valmórbida", a igreja da cidade, o pomar...), é possível dizer que, neste momento, poeta e leitor se deparam com uma viagem mais no tempo do que no espaço, já que agora a viagem se fixa nesse ponto específico do estado e da memória que é Garibaldi.

A viagem reinicia num pequeno bloco de 3 (três) poemas que se passam em Bento Gonçalves e nas suas imediações e que antecedem uma terceira e última parada. Esse bloco funciona quase como uma síntese das características gerais da obra, as quais serão analisadas no momento devido: o movimento de memória em flash back; a prosopopéia; o uso de palavras e elementos da cultura italiana; a recorrência aos elementos cristãos; a predominância do cenário, da ambientação como que fundida ao personagem-narrador; e o lirismo.

As lembranças do poeta revelam um certo estranhamento frente ao cenário observado que, se se apresenta novo aos olhos devido à passagem do tempo, permanece o mesmo na memória do viajante. Esse cenário, outrora sempre ensolarado e alegre (talvez porque a memória seja mesmo seletiva e só guarde o que lhe apraz), reaparece vestido de inverno, num primeiro passo manso - vestido de orvalho -, num segundo mais decidido vestido de neve ("A terra mudou o vestido - acordou toda de branco, / como se, mística e pura, tivesse tomado o véu / (ou a primeira Comunhão?)" (FORNARI, 1975, p. 51)). Mas a essa mudança não está relacionada uma idéia negativa na medida em que a descrição de um cenário frio equivale, ou em muito se aproxima, ao cenário europeu. Assim, se se tem um distanciamento do idealizado pela memória pessoal, tem-se também 
uma avizinhação do idealizado pelo desejo do grupo, qual seja, o de retorno à pátria ou o de transformação da nova terra em nova pátria, de preferência, com a vestimenta daquela.

O último bloco é composto por 4 (quatro) poemas enigmáticos, que não dão nenhuma chance ao leitor de saber se o poeta fica nessa última parada (na cidade de Caxias do Sul) ou se continua em viagem e são suas lembranças em flash back que produzem tal sensação.

O inverno prenunciado no último poema do bloco anterior está agora plenamente instaurado, assim como todas as características e artifícios poéticos utilizados pelo autor ao longo da obra. $\mathrm{O}$ frio branco toma conta de toda a ambientação, desde aquela física (a paisagem) até a mais etérea que talvez se possa chamar de alma poética. $\mathrm{O}$ frio congela as imagens que atuam diante dos olhos do leitor como um close que permite que cada detalhe seja vislumbrado: a exaltação da paisagem (européia); a sublimação das qualidades e virtudes dos colonos italianos; o vocabulário de acentuação italiana; os valores morais de trabalho e fé cristã; o lirismo extremado.

Em meio a esse cenário frio, o viajante busca e recebe abrigo na casa de um desconhecido. Mas ele é italiano, então, enquanto o poeta aproveita para elevar o bom caráter dos seus antepassados ("Almas puras como a neve que branqueia nos telhados" (FORNARI, 1975, p. 53)), o viajante recebe abrigo, o calor amigo e até uma polenta ("Junto ao fogo da lareira / da casa do colono que me abriga sem me conhecer, / aqueço as mãos exangues e geladas, / enquanto a velha nonna, quase centenária, / vai mexendo, remexendo, mexedeira, / a polenta na caldeira" (FORNARI, 1975, p. 52).

E, quando tudo parece congelado, o poeta, mais uma vez, surpreende com a chegada de um novo personagem: a Primavera ou, como ele chama, "a dona Primavera, linda, estranha, vaporosa, cheirosa de entardecer...” (FORNARI, 1975, p. 56).

A Primavera vem para instaurar a esperança da mudança, do novo e da beleza. Ela propicia a "Ressurreição floral das almas e das seivas, / das montanhas e dos vales, / dos caminhos e dos rios, / da terra toda, que é, agora, um novo e vasto jardim! / [...] todo o universo é agora um prenúncio de venturas / e uma promessa de amor." (FORNARI, 1975, p. 57).

Nesse último poema ("Dona Primavera") a fusão entre o viajante narrador, eu-lírico e ambientação chega ao extremo. Já não se pode mais diferenciar ambientação de personagem, já que a Primavera aparece realmente como uma mulher maravilhosa que enlouquece "os homens (velhos, moços e meninos)", que "sorri aos curiosos", que tem "gestos alados" e "passos sonoros". E já não se pode mais diferenciar eu-lírico / narrador dessa ambientação já híbrida: "E até eu, vibrante e zonzo, / qual se andasse 
alguém raspando / um arco de violoncelo nos meus nervos afinados, / ó dona Primavera! / por ti, que tantas músicas semeias, / trago pássaros cantando, / empoleirados / na galharia azul das minhas veias!" (FORNARI, 1975, p. 57).

\section{AS VIAGENS PELO TEMPO}

À travessia geográfica analisada até aqui entrecruza-se uma outra travessia, a qual ainda se desdobra em tantas outras, que é aquela através dos tempos, seja o tempo linear, aquele passível de ser cronometrado, seja o tempo dissolvido no espaço da memória. Essa viagem temporal (ou essas viagens temporais) também produz(em) modificações no viajante. Enquanto a mudança propiciada pela viagem geográfica é de caráter visual ou habitual, isso é, o viajante passa por novos lugares e, observando-os, habitua-se (ou não) a esse novo contexto físico, a mudança proporcionada pela viagem de caráter temporal se relaciona mais a uma transformação pessoal e interior do viajante ou do grupo em que ele se insere ou que representa.

Essa viagem temporal é bastante complexa na medida em que, partindo do suposto de que seu espaço de desenvolvimento seja a memória, a referência que se estabelece a partir daí é múltipla, já que a memória retém movimentos de passados longínquos (de acordo com a Psicanálise, desde o experienciado no útero materno) até movimentos de idealizações futuras. A esse respeito, comenta Maria Alzira Seixo:

$\mathrm{O}$ espaço da viagem centra um entrecruzamento dos vários níveis temporais (passado, futuro, presente pontual, presente durativo, suspensão interrogativa da subjetividade) e acentua a solidão de uma entidade confinada à identidade, sem outro que a delimite, ou recusada, por negativa, a alteridade que a terra the fornecia, e nessa medida se perdendo ela própria... (SEIXO, 1998, p. 36).

Se é verdade que é no espaço físico que um determinado ser trava um primeiro contato com um outro, é também verdade que é no espaço temporal que esse contato se efetivará, isso é, é no espaço interior de cada um desses seres que o outro encontrará lugar (ou não) para a sua afirmação enquanto tal. Se a presença física se marca no espaço, a presença identitária (assim entendida como o complexo de caracteres psíquicos, culturais, sociais...que constituem um sujeito propriamente dito) se delimita no espaço temporal, que é o lugar onde se operam todos os referenciais de comunhão com o outro ou de reação a esse. E uma vez estabelecida essa relação, o sujeito (viajante) está apto a enfrentar a travessia, que nada mais é do que a passagem de um termo a outro, a mudança de um ser a outro. 
Isso não quer dizer que esse ser primeiro se anule ou se transforme em algo completamente novo, mas sim que a esse ser são acrescidas outras tantas características ou traços que num primeiro momento eram desconhecidos e que, agora, depois de feita a travessia, são parte constituinte desse ser. Quanto maior a viagem, quanto mais numerosas forem as travessias, quanto maior o contato entre seres diversos, mais diverso e híbrido será também o viajante. Essa dinâmica é explicada por Maria Alzira Seixo da seguinte forma:

O outro enquanto entidade torna-se elemento constituinte fundamental da noção de travessia (e desejo dela, pela necessidade de imersão), que sem ele poderia restringir-se a um simples alargamento ou difusão. Também a entidade-outro começa quando a travessia acaba, e por isso participa na configuração da mudança como outra face da travessia, co-participante da determinação do espaço na sua contaminação temporal, uma vez definida a deíxis integral (espaço $\mathrm{x}$ tempo) que faz desaparecer a margem quando se atingiu o seu termo. Forma-se assim uma dinâmica que integra objetos, sujeito, espaço, tempo, meios e operações, e que, em termos de morfologia discursiva, procede à articulação da narrativa, rigorosamente homóloga, nestas condições, do próprio processo da viagem na sua dimensão escrita (SEIXO, 1998, p. 24).

Essa busca incessante entre dimensões físicas e temporais dos vários eus e outros, talvez seja, junto com raciocínio lógico, o que distingue os homens dos outros animais. E o que talvez os identifique enquanto Reino (na definição biológica) seja o fato de não conseguirem, uns e outros, viverem sozinhos. O grupo, o coletivo, nesse sentido, é também marca constante no movimento da viagem. Sobre esse argumento, diz Octávio Ianni: “...o caminhante não é apenas um 'eu' em busca do 'outro'. Com freqüência é um 'nós' em busca dos 'outros'. Há sempre algo de coletivo no movimento da travessia..." (IANNI, 1996, p. 16).

Essa necessidade de convivência, de busca de um outro, gera o que habitualmente se tem chamado de alteridade $e^{5}$. Mas o perigo no emprego de tal termo vem exatamente pelo fato já exposto anteriormente, que é o do medo, da não aceitação do outro assim como ele é e do desejo de homogeneizá-lo às características já conhecidas, aceitas e assimiladas. Portanto, é importante frisar que em Trem da serra o que se tem não é exatamente um "spectacle de l'altérité", como categorizaria Wladimir Krysinski (1998, p. 295), mas uma procura da alteridade. Isso não invalida nem minimiza o valor da obra, ao contrário, levando-se em consideração a

5"Pode-se chamar alteridade ao sentimento do outro, isto é, de ver-se o outro em si, de constatar-se em si o desastre, a mortificação ou a alegria do outro. Passa a ser assim esse termo o oposto do que significa no vocabulário existencial de Charles Baudelaire - isto é, o sentimento de ser outro, diferente, isolado e contrário" (ANDRADE, 1970, p. 141). 
época e o contexto social em que foi escrita e, principalmente, o grupo étnico que representa, isso deve ser percebido como um passo inovador. Talvez se possa mesmo dizer que Trem da serra, além de inaugurar a Poesia serrana enquanto categoria, funda também as bases para uma literatura verdadeiramente altera (o que também é questionável se levarmos em consideração o posicionamento de $\operatorname{Hartog}^{6} \mathrm{e} o$ fato de tal literatura ainda não estar presentificada com a devida força e maturidade no Brasil).

\section{VIAGEM DE PROCURA IDENTITARIA (Eu = Grupo)}

Retomando a divisão em blocos poéticos estabelecida na primeira parte do presente estudo, pode-se dizer que já no segundo bloco é inserida uma imagem crucial para a análise da obra e que inaugura esse tipo de viagem, o de procura identitária. A imagem do colono, do imigrante italiano ou de descendência italiana, é traçada a partir de duas referências básicas: seus valores morais (calcados no trabalho) e na sua fé religiosa.

Nesse ponto parece importante que se discorra, ainda que brevemente, sobre essas duas características, que são extremamente peculiares no que concerne ao grupo de imigrantes italianos. Antes de mais nada, é preciso lembrar que a idéia de grupo ou comunidade, baseia-se naquilo que seus componentes têm de comum, seja sua cultura, seus costumes, sua língua ou suas crenças. Acontece que essa homogeneidade não pode ser aplicada de modo algum à comunidade italiana. Deve-se ter sempre presente que, nas palavras de Constantino,

a Itália foi tardiamente unificada e nossos imigrantes transportaram bagagem cultural muito diferenciada. Falavam vários dialetos, praticavam diferentes cozinhas, enfim, tinham usos, costumes e tradições diferentes uns de outros grupos. Como poderiam, de início, apresentar italianidade, se grande parte de nossos imigrantes desconheciam o idioma de Dante e se nem mesmo haviam desenvolvido a concepção de pátria unificada? (CONSTANTINO, 1994, p. 91).

Por isso, e pela necessidade de se negociar essa multiplicidade cultural com uma outra cultura também múltipla, a brasileira e, mais especificamente, a gaúcha, os italianos entrados no Rio Grande do Sul processaram um tipo de catolicismo bastante diferente daquele professado pelos católicos alemães ou poloneses aqui chegados. De acordo com De Boni, os imigrantes italianos

${ }^{6}$ Françoise Hartog (1999, p. 270-271), em conclusão ao capítulo intitulado "Uma retórica da alteridade", diz que não há, na realidade, um caminho que leve à perfeita alteridade, uma vez que um terceiro elemento é necessariamente criado a partir de dois outros numa relação de constante tradução. Esses termos não se anulam, não se fundem, tampouco complementamse por inteiro. Grosso modo, o que pode existir são tentativas, mas nunca se atingirá a dissolução desse binarismo. 


\begin{abstract}
mantiveram uma distinção entre pátria e religião. Sem dúvida, sabiam que seu modo de praticar o catolicismo eram-lhes peculiar [...], mas nem por isso eram levados a associar os sentimentos de religião com os de pátria. Há explicações para tanto, desde a falta da noção de pátria na Itália de 1870 [a primeira imigração foi em 1875], na qual indivíduos professavam lealdade étnica e cultural a uma região e não a um país, até o fato de que o novo reino instalara-se em oposição ao papado (DE BONI, 1994, p. 103).
\end{abstract}

Dessa forma, "o trabalho acaba por adquirir um significado éticoreligioso quase autônomo e torna-se um parâmetro para medir o valor moral das pessoas. Ser bêbado, blasfemar, e praticar outros atos condenados pelo grupo, com exceção de matar e roubar, tudo pode ser desculpado, em boa parte, se o indivíduo é trabalhador" (DE BONI, 1994, p. 105). Além disso, como lembra Morosini, os italianos "buscavam no país de imigração as oportunidades de trabalho que lhe foram negadas na Itália, buscavam sobretudo a posse da terra em que trabalhavam. Demonstravam a força da individualidade neste processo de ascensão social; respaldavam-se numa ideologia onde a poupança merecia destaque e a contenção de despesas vigorava" (MOROSINI, 1987, s.p.).

É nesse âmbito e com base nessa compreensão que Ernani Fornari personificará os imigrantes italianos em Trem da serra. O dito "Deus ajuda quem cedo madruga" (versão do italiano: L'aurora porta l'oro in bocca, em que não estava presente a idéia de Deus, mas a do trabalho por conta própria) está implícito em toda a extensão da obra e explícito no sétimo poema desse bloco (FORNARI, 1975, p. 14: "Despertar”): “- Desperta, indolente, que os outros trabalham, / e é um crime dormir na hora da ação!”. Tanto os colonos quanto os imigrantes urbanos de Trem da serra são confiáveis, honestos e de boa índole exatamente porque trabalhadores. E sua moral religiosa opera também de acordo com esse princípio.

Assim, não é de se admirar que ao imigrante italiano se contraponha o nativo brasileiro, figurado muitas vezes por uma visão depreciativa, de incapacidade ou de falta de fé nas crenças declaradas como válidas, como se pode observar no quinto poema desse bloco (FORNARI, 1975, p. 10-11: “Trailler”): “Agora, / uma choupana, com ar triste de mendiga, / sem horta, / sem chiqueiro, / sem roçado, / com paredes de taquara, lata e barro, / a formar grandes barrigas: / - casa cai-não-cai do caboclo ${ }^{7}$ verminado...// Agora, / num cenário de fartura, / um chalé muito claro, rodeado de verduras, / cheiroso de tremoço, recendendo a todo vinho: / lar de colono que entendeu toda a bondade / do chão que os outros pisam sem carinho... // Agora... / que foi mesmo que passou? // - Uma tapera -

${ }^{7}$ Ver nota 5. 
esperança que falhou....”.

Essa visão receosa a respeito do outro explica-se pelo fato de o outro ser diferente. Na verdade, é impossível amar a quem não se conhece, pelo contrário, o desconhecido provoca medo e desconfiança, que, em geral, vem revestida por uma atitude de desprestígio frente ao outro. Como se pode considerar capaz ou de boa índole alguém que não se conhece? Darcy Ribeiro, a esse respeito, reconhece que os imigrantes “...olhavam suspeitosos os negros e mestiços que formavam a maior parte da população e explicavam o atraso prevalente no país pela inferioridade racial dos povos de cor" (RIBEIRO, 1995, p. 436). Se não se pode aceitar essa posição por parte dos imigrantes e seus descendentes, devido ao caráter absolutamente preconceituoso que revela, é importante que se procure compreender a base de tal comportamento, uma vez que eles próprios enfrentavam esse mesmo desrespeito por parte dos seus iguais. É necessário lembrar que o primeiro movimento imigratório só ocorreu devido às condições totalmente precárias que a Itália oferecia ao seu povo aliadas à usurpação de toda e qualquer esperança de melhora. Essa é uma questão delicada de se abordar devido à sua complexidade. Por ora, tentar colocarse nesse lugar incômodo que era o de "não estar de todo" em lugar nenhum, nem no seu país de origem nem no país que passa também a ser seu, pode, talvez, ajudar no entendimento de como foi (e ainda é) difícil esse enfrentamento.

Por toda essa dificuldade de compreensão sua (do imigrante italiano) e do outro (brasileiro, ou caboclo), parece certo que a noção de Pátria, como já referido anteriormente, esteja ainda emaranhada. Por um lado, não se sabe ainda o que é, por outro, deseja-se que seja uma coisa só, por outro ainda, percebe-se a impossibilidade de ser única, já que engloba uma imensidade diversificada, mas não se perde a esperança de uma utopia possível. Tal movimento se percebe no oitavo poema desse bloco (FORNARI, 1975, p. 15: "Profecia): "(Por certo, um dia, nós também seremos / um povo construtor, como os joões-de-barro! / Ah! nesse dia, então, nossas estradas todas / também hão de se dar as mãos sem fim, / e a nossa terra agora descuidada, / tão isolada em sua vastidão, / será uma Pátria só, a Grande Pátria, enfim, / única, / unida, / tal e qual, / assim!)”. Nessa passagem fica evidente a dificuldade de inserção do poeta enquanto um ou outro. Fala de "nós", mas esse nós tanto pode estar se referindo a brasileiros, quanto a italianos, quanto a imigrantes, quanto a seus descendentes! A idéia que parece mais se ajustar à perspectiva de toda essa obra é que o poeta se pretende brasileiro mas ainda não conseguiu perceber-se enquanto tal, mas sim enquanto italiano, ou mais especificamente fiorentino, e conclama a si e aos seus a posse da terra e o direito de transformá-la para adequá-la aos seus valores e aos seus objetivos. Aqui não se deseja nenhum julgamento de valor, apenas constata-se o que já 
foi discutido anteriormente quanto à ideologia vigente pela imigração, o que, até certo ponto, é representativo de uma visão ingênua mas muito esperançosa e decidida em relação à concretização de seus ideais.

Obviamente essa esperança passa pelo desejo não só de uma nação unificada mas pela idealização da América; a América como o continente dos sonhos, como a terra prometida e que presenteará com fartura aqueles que nela e por ela trabalharem. Tal pensamento está também presente no decorrer de toda obra mas aparece no sexto poema desse bloco (FORNARI, 1975, p. 12-13: "Episódio - de um filme em série") de maneira inusitada, contrapondo realidade e ficção e trazendo à tona a visão cinematográfica de Fornari: "Adormeço.../Adormeço pensando que gosto mais dos filmes americanos, / porque, neles, / as casas são sempre novas, / as paisagens são sempre belas, / e as histórias terminam sempre bem, / com lutas sempre vencidas / por um 'mocinho' valente e forte como ninguém...". Certo que essa América de que o poeta fala é aquela do norte, distante da realidade Pau-Brasil, mas também é certo que na época da imigração os que da Itália vieram não tinham noção de distanciamento entre uma e outra realidade e a América funcionava como um bloco único, como a terra da salvação. Mais uma vez a idéia de unificação...

O desconhecimento sobre essa terra que prometia esperanças é relatada de maneira simples e comovente pelo imigrante Pietro Ferronatto, vindo da cidade de Bessega para o Rio Grande do Sul em 1885:

A vinda ao Brasil era considerada grande aventura, por ser uma terra totalmente estranha e muito falada. Muitos italianos pensavam que, no Brasil, não existia madeira e traziam até cabos de madeira para colocá-los em suas ferramentas. [. . .] Ninguém sabia o que era o Brasil. Aqui viemos para melhorar nossas condições de vida. Nossa viagem durou quarenta dias. Muitos faziam planos fantásticos para uma realidade que foi totalmente diferente. Enfrentamos tempestade e ventos em alto mar. [.. . ] Por falta de recursos, eu e minha família fizemos o trajeto de Porto Alegre até Alfredo Chaves a pé. Outras famílias fizeram o mesmo. As estradas deviam ser abertas e a única solução era abrí-las a facão, íamos fazendo a 'picada', rumo ao nosso destino. Não conhecíamos nem foice, nem podões. No final de cada jornada, parávamos para acampar e a mãe nos preparava a comida. Após vários dias de lutas, chegamos até a Colônia Dona Isabel. [. . .] Começamos a nossa vida, plantando milho, criando porcos e galinhas e iniciando nosso parreiral, que ainda é tradição da família (COSTA, 1986, p. 70).

Esse desconhecimento geográfico e físico se processa da mesma maneira que o desconhecimento do outro, como já foi discutido. E o único movimento capaz de quebrar essa barreira e de colocar em contato culturas diversas é o da viagem (nos seus múltiplos sentidos, também já levantados no presente estudo). Viajar é colocar em relação, colocar em relação 
é comparar, e uma comparação, se desenvolvida com base no respeito mútuo pelas diferenças, pode levar ao estabelecimento de uma relação altera e proveitosa para todos os objetos participantes do processo.

Octavio Ianni se manifesta a respeito:

A viagem pode alterar o significado do tempo e do espaço, da história e da memória, do ser e do devir. Leva consigo implicações inesperadas e surpreendentes. O Velho Mundo somente começou a existir quando os navegantes descobriram o Novo Mundo. [... . ....com a invenção do Novo Mundo alteram-se a geografia e a história, compreendendo os sentidos de espaco e tempo, e envolvendo uma transformação radical dos quadros sociais e mentais de referência (IANNI, 1996, p. 11).

A percepção de que existem mundos diversos leva à compreensão da multiplicidade étnica, cultural, religiosa e das diversas formas de organização social. Saber que, em um processo emigratório, está-se deixando para trás uma série de valores que não serão encontrados em um novo lugar e que tampouco poderão ser recuperados de todo, por maior que seja o esforço de manutenção por parte desses viajantes, é já um passo em direção à construção de um "entre-lugar"s , que é o lugar por excelência da alteridade. Na verdade, o que se cria a partir de uma aceitação desse gênero é um terceiro termo: não mais italiano, ainda não brasileiro, mas um imigrante, um viajante, um ítalo-brasileiro, como explica Darcy Ribeiro:

Apesar do isolamento, sabiam que aqui teriam de viver, tanto mudara o seu país de origem e tanto haviam mudado eles próprios, afastando-se dos padrões europeus, nos hábitos, na linguagem e nas aspirações. Os novos contingentes recém-chegados serviam para contrastar o seu sotaque e a sua ignorância do mundo cultural longínquo de que se desgarraram suas famílias. Mas o convívio simultâneo com índios, matutos e gaúchos recordava-lhes, também, quanto se diferenciavam dos antigos ocupantes da terra, por cujos modos de vida miseráveis não podiam sentir qualquer atração. Esses eram, de um lado, seus patrícios e, de outro, os brasileiros que conheciam. Eles mesmos sentiam constituir uma terceira entidade, irredutível a qualquer daquelas formas (RIBEIRO, 1995, p. 439).

No poema "Estação de parada"9 (p. 24 - terceiro bloco, parada

\footnotetext{
${ }^{8}$ Termo usado pela primeira vez no Brasil por Silviano Santiago (2000, p. 9-26).

9

Gente que desce, apressada;

gente que sobe, impaciente

gente que espera, nervosa,

e toda uma turba de louros, morenos e ruivos bulhentos

fundindo ao cadinho do Sol

um idioma novo e singular

que todos falam gritando,
} 
na cidade de Montenegro), Ernani Fornari continua essa complexa discussão sobre a questão identitária, já conseguindo dar um tratamento mais solto, mais colorido, em reverência a um procedimento de aceitação da multiplicidade. O que é exaltado agora é o múltiplo, o híbrido. E é esse híbrido que doravante irá sustentar todo o livro, toda a viagem.

Essa mescla está presente também na forma poética que, nesse bloco, prima pelo lirismo, ora amoroso, ora melancólico, ora auto-reflexivo. Isso talvez se explique exatamente pelo fator aceitação do diverso, que permite ao poeta vislumbrar a beleza de cada parte que compõe o todo, que permite ao poeta torna-se cada vez mais sensível ao outro e à compreensão de si próprio (o que, por sua vez, o leva a pesar fatos passados).

\section{VIAGEM “AO REDOR DE MIM MESMO” (EU ? Grupo)}

Ainda no terceiro bloco, percebe-se que o segundo poema, intitulado "Felicidade - drama da vida real" (p.18-19), figura como exemplo de uma auto-reflexão melancólica e de uma procura quase desesperada pela pureza ou pela perfeição, tanto da identidade do grupo quanto da identidade particular do viajante. É nesse ponto que o poeta começa a questionar a própria existência ou o resultado produzido por ela. E desse questionamento emana a certeza de que esse lugar fixo e tão almejado por todos não existe ou não se faz claramente percebido, ao menos não no fixo mas, talvez, no fluido: "Fiquei convencido, desde então, / que onde mora a Felicidade não há estação! / - a gente passa sem parar...".

Aqui o viajante toma consciência de que não só não existe uma identidade pura como também não existe um estado de espírito único ou uma Pasárgada onde todos são imutavelmente felizes. É essa consciência que permite ao poeta a exaltação do diverso, do movimento constante, do mesclado e do híbrido.

ilustrando com acenos e sorrisos

o falar.

Embora eu não compreenda muita coisa do que dizem, agrada-me aos ouvidos a harmonia colorida

dessa colcha de retalhos dialetais

em que há muito de italiano, de alemão e castelhano

misturando ao português.

Mas, súbito, uma dúvida pungente

Se insinua em minha mente amedrontada:

Ah!

Estarei na minha terra? Será este o meu Brasil?...

"não permita Deus que eu morra

sem que volte para lá"! 
Tal consciência, no entanto, só pôde ser alcançada mediante um despojamento daqueles valores arraigados e já discutidos aqui mas que valem ser lembrados: a idéia de uma etnia pura, os preceitos morais e religiosos tidos por únicos, a ilusão de que o povo perfeito estava chegando na terra perfeita e que agora se tornaria próspera, completa, acabada e definitiva. Mas no seio de um movimento coletivo há também um movimento individual (não se pode esquecer que o coletivo é constituído por vários indivíduos), e esse movimento, paralelo àquele, e muitas vezes dele proveniente, constitui-se como busca de uma identidade individual, como busca da compreensão do "quem sou eu". Sobre tal argumento, manifesta-se Octavio Ianni:

Ainda que se despoje no longo da travessia, procura algo de si, do que tem sido, do que foi. Por mais que se liberte e abra ao novo e desconhecido, ao que parece não codificado, sem face nem nome, ainda assim agarra-se ao que era, foi e continua a ser. Isto porque muitas vezes o viajante está à procura de si mesmo (IANNI, 1996, p. 18).

Retomando-se o quinto bloco poético, tem-se a predominância de um caráter auto-reflexivo e autobiográfico devido, provavelmente, ao fato de a cidade visitada (Garibaldi) ter sido parte significativa da juventude do poeta viajante, como o já analisado anteriormente. Daí também o fato da narração dos passeios feitos nessa cidade (tanto aqueles externos, através das ruas e lugares queridos ao viajante, quanto aqueles internos, através das suas memórias) adquirir um caráter cinematográfico.

Esse movimento poético-narrativo cinematográfico mistura um close agudo em cada canto da cidade e um flash back que faz com que cada canto da memória seja revisitado. Para Iris Körbes $(1984$, p. 4) "O poeta-passageiro instaura uma 'situação cinema ${ }^{10}$ '. A paisagem que desfila diante da janela do trem, 'tela', é revivida como uma sucessão de imagens de cinema, imagens que trazem à tona vivências da infância".

Assim, o lirismo, como não pode deixar de existir no âmbito das lembranças, é reativado, bem como a recorrência de elementos cristãos. Esses elementos, como já se observou, estão presentes em toda a obra, mas nesse bloco eles são especialmente empregados, talvez pelo fato de estarem amplamente relacionados à educação católica que o poeta teve. $\mathrm{O}$ dia santo, a missa, Deus e o amor sublimado são fortemente requisitados pelo poeta

10"Para Christian Metz [METZ, Christian et alii. Psicanálise e cinema. São Paulo, Global, 1980, p. 64.], o cinema instala um regime especial de consciência - a 'situação cinema', 'situação fílmica'- que estabelece um fenômeno de fronteira entre a vigília e o sono, instaura um 'sonhar acordado'. O filme, neste caso, funciona como um elemento de prazer compensatório, ele nos transporta ao imaginário; nesta instância, um jogo identificatório se alterna entre um $e u$ (espectador) e um $t u$ (na tela). Esse jogo de identificação permanente com a personagem é que determinaria a 'situação cinema', em que o espectador se projeta e se vê projetado, sempre numa relação de identificação e desvendamento. Essa relação de identificação com o que é visto na tela é condição para o prazer e a satisfação afetiva" (KÖRBES, 1984, p. 5). 
talvez no que se possa chamar de tentativa de purificação das memórias.

Ainda sobre esse bloco e, mais especificamente, sobre o poema "Garibaldi - pátria das minha "primeiras vezes"”, pondera Iris Körbes:

A dona da voz amorosa sumira no tempo. $\mathrm{O}$ velho não encontra mais o menino. O menino, o adolescente, o velho é um só. Por meio dessa viagem, aprendera que o passado é irreversível e ninguém retorna a ele impunemente. $\mathrm{O}$ defrontamento com os próprios limites da memória, reduto em que se aloja o menino, o adolescente, o homem maduro, o velho, é o momento totalizante do poeta. O passado é matéria da memória. É nesse emaranhado mítico que penetramos, tentando deslindar a luta com seu inimigo (o esquecimento) no significativo confronto no centro da praça - a pátria das "primeiras vezes" (KÖRBES, 1984, p. 75).

Retomando-se, agora, o último bloco de poemas de Trem da serra, mais propriamente o poema "Caxias sobre a neve" (FORNARI, 1975, p.52-53), aquele em que o poeta canta a amizade com que fora recebido imigrantes ("Junto do fogo da lareira / da casa do colono que me abriga sem me conhecer, / aqueço as mãos exangues e geladas, / enquanto a velha nonna, quase centenária, / vai mexendo, remexendo, mexedeira, / a polenta na caldeira."), tem-se a situação limite da condição do viajante:

Esta passagem confirma a condição do poeta exilado, sempre um "passageiro", um errante em busca do outro, do outro eu. [...] A casa, mesmo de um desconhecido, representa um refúgio, um abrigo para o poeta e põe em relevo a sua condição de ser desencontrado e extraviado; igualmente a velha centenária traduz simbolicamente uma figura de proteção, de amparo. É uma imagem de enraizamento. E parece invulnerável ao tempo (quase centenária) do qual é uma imagem mítica. Ainda, a casa em que desemboca o poeta no final da travessia pode também simbolizar um "regressus ad uterum". O recinto restrito e fechado, aliado a outros elementos (velha centenária, ferreiro) e a ambientação toda do cenário final suscitam essa imagem de volta para dentro, uma interiorização, um retorno à origem, um regresso ao útero. Deste estado regressivo um novo ser renasce; é um recomeço que se abre para novas dimensões (KÖRBES, 1984, p. 98-99).

Esse recomeço parece um movimento permanente em Trem da serra, seja pela discussão identitária (tanto a identidade do grupo quanto aquela própria do poeta viajante), seja pela viagem propriamente dita. Iris Körbes $\left(1984\right.$, p. 9) ${ }^{11}$ acredita que a viagem geográfica acaba na cidade de Caxias assim como que é ali que o poeta dá por terminada a "busca de si

11“... a cena dramática final, centrada no interior da casa do desconhecido em Caxias, onde, numa nova ambientação simbólica, termina a busca de si mesmo, na revelação do outro eu, da outra voz. Suprimida a dualidade, o poeta chega ao fim da trajetória percorrida pela experiência poética em direção a um ponto imaginário, onde estaria o 'paraíso perdido', a unidade original" (KÖRBES, 1984, p. 9). 
mesmo". Mais adiante (FORNARI, 1975, p. 103 e 104) a autora afirma que a "revelação do outro é alcançada e o ser atinge sua totalidade e identidade". Mas uma análise minuciosa da obra não parece permitir tal interpretação tomando-se por base várias indicações do poeta / narrador sobre as quais se pretende, ainda que brevemente, discorrer.

Em primeiro lugar deve-se ter presente que não existe uma indicação precisa de um ponto de partida e tampouco há, por parte do viajante, uma explicitação de qual seja o seu objetivo da viagem ou até onde pretende ir. Não se sabe se ele já vinha viajando e resolve narrar essa viagem a partir da cidade de Pareci (e da mesma forma poderia simplesmente decidir parar de narrá-la ao chegar em Caxias), assim como não se sabe se essa viagem visa a negócios, se visa ao encontro de alguém, da família, de um amigo, de uma amada... Não há realmente nenhuma indicação a respeito do objetivo dessa viagem assim como não se pode afirmar categoricamente que ela termine quando o viajante chega em Caxias. Se se tem essa sensação é porque é nesse ponto que a narrativa se encerra, mas é somente a narrativa que termina, talvez não a viagem.

O que parece corroborar essa interpretação é o fato de o viajante abrigar-se em uma casa estranha. Ora, se seu objetivo fosse mesmo terminar a viagem nessa cidade, imagina-se que teria já alguma estrutura à sua espera: a casa da família, de uma amigo, de uma amada, um quarto alugado pela empresa em que trabalha ou um reservado por ele mesmo em algum hotel... Talvez Caxias seja mesmo a última cidade a ser visitada nessa viagem e o poeta narrador faça o percurso inverso, voltando ao seu ponto de origem. Mas também disso não existe nenhuma indicação (assim como também não se sabe o ponto de origem)!

Quanto ao fim da busca de si mesmo também parece impossível qualquer afirmação taxativa, a não ser que essa fosse a fusão total entre personagem / viajante e natureza / ambientação / paisagem, porque esse é o único indício concreto que o poeta oferece: "E até eu, vibrante e zonzo, / qual se andasse alguém raspando / um arco de violoncelo nos meus nervos afinados / ó dona Primavera! / por ti, que tantas músicas semeias, / trago pássaros cantando / empoleirados / na galharia azul das minhas veias!" (FORNARI, 1975, p. 57).

Mas o poeta / narrador ainda não se decidiu se é homem, árvore, instrumento musical! Assim como não se decidiu se é italiano, brasileiro, ítalo-brasileiro. E essa decisão também não parece em nada necessária na medida em que essa é a discussão proposta e na medida em que a viagem é o movimento constante, é a busca constante. E se a viagem não acaba (ou se não há indícios verdadeiramente concretos para tal afirmação), como podem acabar as dúvidas, como pode dar-se a busca por encerrada? 


\section{CONSIDERAÇÕES FINAIS}

Com a certeza de não ter-se dado conta de toda a complexidade que envolve a obra Trem da serra, de Ernani Fornari, mas de, ao menos, ter-se apontado novos caminhos de leitura e investigação para uma obra tão preciosa e ainda tão pouco apreciada, termina-se aqui essa singela análise que pretendeu abordar a obra do ponto de vista da literatura de viagem. Parece claro que também a partir desse recorte muito ainda se deixou de fora, mas acredita-se ser esse o verdadeiro mistério da literatura: o de nunca esgotar-se.

Assim como François Hartog se refere ao thôma, declarando que quanto mais thôma, mais maravilhas, maior e melhor será também a viagem, afirma-se aqui que quanto mais profunda a leitura de uma obra literária, mais possibilidades de interpretação surgem. Uma boa obra e que ainda possui o agravante de se colocar fora do alcance de qualquer classificação ou esquema é mesmo um inesgotável manancial de significados, um produtor de maravilhas. Parece inquestionável a inserção de Trem da serra em tal contexto.

E assim termina (ou não) a viagem desse homem-ambiente, narrador-narrado, poeta-poesia, que é meio homem meio árvore, meio italiano meio brasileiro, meio trem e meio trilho, e que não cessa nunca de andar um tanto à frente e um pouco atrás, revendo os valores que construíram toda uma comunidade e instituíram uma cultura e que, entrando em contato com um cenário que não é o seu, esforça-se por integrar-se a ele, ainda que numa tentativa utópica de unificá-lo.

\section{BIBLIOGRAFIA}

ANDRADE, Oswald. Um aspecto antropofágico da Cultura Brasileira: o homem cordial. In: _. Obras completas: do Pau-Brasil à Antropofagia e às Utopias. 2ed. Rio de Janeiro, Civilização Brasileira, 1970.

CONSTANTINO, Núncia Santoro de. Ítalo-gaúchos: imigrantes na cidade e identidade étnica. In: _. . Diversidade étnica e identidade gaúcha. Santa Cruz do Sul, UNISC.

COSTA, Rovílio. Imigração italiana no Rio Grande do Sul. Porto Alegre / Caxias do Sul, EST / EDUCS, 1986.

DE BONI, Luis Alberto. O catolicismo da imigração italiana. In: _. . Diversidade étnica e identidade gaúcha. Santa Cruz do Sul, UNISC, 1994. 
DIÉGUES JÚNIOR, Manuel. Etnias e culturas no Brasil. Rio de Janeiro, Civilização Brasileira, 1977.

DIMAS, Antonio. Espaço e romance. 3ed. São Paulo, Ática, 1994.

FAÉ, Walter José. Italianos no Rio Grande do Sul (1875-1975). Americana, FOCAM, 1975.

FORNARI, Ernani. Trem da serra. 2ed. Porto Alegre, Acadêmica, 1987.

HARTOG, François. Uma retórica da alteridade. In: _. O espelho de Heródoto - ensaio sobre a representação do outro. Trad. Jacyntho Lins Brandão. Belo Horizonte, UFMG, 1999.

IANNI, Octavio. A metáfora fora da viagem. Cultura vozes. São Paulo, v.90, n.2, p.3-19, mar./abr. 1996.

KÖRBES, Iris. Trem da serra: uma viagem de desvendamento. Porto Alegre, 1984. Dissertação (Mestrado em Literatura da Língua Portuguesa) - Instituto de Letras, Universidade Federal do Rio Grande do Sul, 1984.

KRYSINSKI, Wladimir. Vers une typologie des récits de voyage: structures, histoire, invariantes. In: SEIXO, Maria Alzira, ABREU, Graça (Orgs.) Les récits de voyages - tupologie, historicité. Lisboa, Cosmos, 1998.

MOISÉS, Massaud. Dicionário de termos literários. 7ed. São Paulo, Cultrix, 1995. 520p.

MOROSINI, Marília Costa. Imigrantes que deram certo em Porto Alegre e a esfera de trabalho. Veritas. Porto Alegre, n.32, set. de 1987.

RIBEIRO, Darcy. Brasis sulinos: gaúchos, matutos e gringos. In: _. . O povo brasileiro - a formação e o sentido do Brasil. 2ed. São Paulo, Companhia das Letras, 1995.

SANTIAGO, Silviano. O entre-lugar do discurso latino americano. In: .Uma literatura nos trópicos. 2ed.Rio de Janeiro, Rocco, 2000.

SEIXO, Maria Alzira. Poéticas da viagem na literatura. In: __. Poéticas da viagem na literatura. Lisboa, Cosmos, 1998.

SÜSSEKIND, Flora. O Brasil não é longe daqui - o narrador, a viagem. São Paulo, Companhia das Letras, 1990.

TODOROV, Tzvetan. A conquista da América - a questão do outro. Trad. Beatriz Perrone Moisés. São Paulo, Martins Fontes, 1993. 